\title{
SWOT ANAL YSIS MICRO SMALL MEDIUM ENTREPRISE (MSME) GEULIS CRAFT UMBRELLA TO SUCCESS IN LOCAL ECONOMIC DEVELOPMENT RESOURCES DISTRICT TASIKMALAYA
}

\author{
K. Dianta A. Sebayang* \\ Munawaroh*
}

\begin{abstract}
ABSTRAK
Pengembangan sumber daya ekonomi lokal saat ini menjadi tren baru dalam upaya meningkatkan pendapatan masyarakat dan daerah. Faktor lokal yang terkait memainkan peran pentingn baik dari sisi sumber daya alam (bahan mentah) maupun sumber daya manusia (tenaga kerja).

Makalah ini coba menyajikan bagaimana Usaha Kecil Mikro Menegah Pengrajin Payung Geulis mencoba untuk meningkatkan pembangunan ekonomi yang didasari oleh pengembangkan sumber daya ekonomi lokal di Tasikmalaya. Penelitian ini bertujuan untuk menggambarkan potensi pengusaha yang mencakup kompetensi dan komitmen pengusaha dalam bisnis usaha kecil, dan untuk menggambarkan kekuatan bisnis /posisi kompetitif, profil bisnis serta pengusaha yang dipengaruhi oleh kondisi lingkungan internal dan eksternal lingkungan, dilihat dari sisi positif dan negatif. Penelitian dilakukan pada industri payung geulis usaha kerajinan di Tasikmalaya.

Metode yang digunakan dalam penelitian ini adalah analisis deskriptif dengan menggunakan analisis SWOT. Hasil penelitian menunjukkan banyak masalah yang dihadapi dan sangat kompleks, seperti: rendahnya kualitas sumber daya manusia, modal usaha terbatas, rendahnya akses terhadap pasar, akses kelembaga keuangan / bank tidak ada, ketidaktahuan prosedur administrasi, keberlanjutan dan produksi kapasitas terbatas; ditambah dengan iklim usahatidak kondusif bagi pengembangan UKM dan kewirausahaan.
\end{abstract}

Keyword: Entrepreneurs, industri pengrajin , SWOT,

\section{INTRODUCTION}

Developments of the industrial sector of the large industry based in Indonesia in reality have lost significant momentum and its role in the economic development programs

K. Dianta A. Sebayang dan Munawaroh. Dosen Fakultas Ekonomi Universitas Negeri Jakarta initiated by the government. It can be seen from the inability of major industrial sectors to survive the monetary crises which later expanded into a whole economic crisis. We can say that large-scale industries play a important role that cause the economic crisis, such as high economic cost, dependence on 
government facilities, efficiency and effectiveness of low and collusion between entrepreneurs and bureaucrats.

The above phenomena on the other side to open the eyes of the actors, experts, and bureaucrats as well as other related parties in the economy, to quickly realize that there is need to review the policies, and economic activity to save the economy. This has prompted the government to look at the forces that had received less attention and support, contained in the economic sector of the people, represented by Small and Medium Enterprises (SMEs). With a variety of different characters with great industry, which is bottom-up development can provide significant contributions in the process of national economic recovery.

When the economic crisis hit so heavy and difficult to deal with precise and quick, not exaggerated to say that this is the SME sector which can contribute to hope in order to improve economic conditions, although requiring caution in determining policies and its implementation, in order to contribute the macro level, although the translation could be programs to improve the performance of SMEs in the scope of micro economics.

With a variety of character and scale of enterprises, SMEs have a wide coverage in various regions in Indonesia; so with a serious effort involving various stakeholders in the development it is expected the role of SMEs can improve the welfare of the community in various parts of Indonesia. On the basis of the potential of Indonesia's agriculturebased countries, it is never too late to realize the opportunities of SMEs as a producer of agribusiness products who can also serve agricultural products, livestock and fisheries.

Tasikmalaya city has a strong brand in the development of small and medium enterprises. It is necessary to maintain a market that has been mastered and to penetrate new markets in the region. The potential of micro small and medium enterprises is growing steadily every year. At the end of 2009 recorded 16,248 units spread over 133 centers, the investment value Rp.276.607.782.300, - with a production value of Rp. $1,344,791,876,000$,- and is able to absorb a workforce of approximately 36,472 people. The commodities reached 23 commodities include small industrial embroidery, clogs, furniture, batik, sandals, woven pandanus, bamboo crafts, umbrellas geulis, convection, various kinds of snack food / processed. Craft umbrella geulis in Tasikmalaya admitted that business activity during this can not guarantee the economic viability of families. Activities as umbrella crafters acted only to maintain and preserve the patrimony craft that is not extinct era swallowed. The sale price umbrella that heritage is not stable. One unit of the umbrella, the burden of production starting from the manufacture of paint can order up to pay $\operatorname{Rp} 12,500$. If it is so only sold 
around Rp 15,000 to Rp. 17,000 per unit. The advantage, Rp 2,500 per unit, if there are seasonal orders. While raw material prices, in the form of paper, paint and other raw materials rose and airports still do not want to raise the price umbrella.

Umbrella Geulis Tasikmalaya now is just only a name. The umbrella crafters are only needed when there are exhibitions or guests who want to know the process of making umbrellas geulis.

There are a lot of problem which still needs improvement, like decreasing purchasing power producers, materials for finishing are still to be imported, capital, lack of information about the international markets, government small attention to reach a evenly in each area producers, as well as issues relating to entrepreneurship and competitiveness of their producers are a few issues.

Nevertheless, it does not mean there is absolutely no way or chance to immediately initiate efforts to promote the SME sector. It need more efforts to find innovative, creative, efficient and solutions that are effective until this sector the SME sector can be a formidable and reliable. It does not matter where the dart's point of view this process can begin, the important thing is cooperation dart various stakeholders, and commitment to perform its functions as possible. Government with its affiliated agencies and authorities can establish relevant policies, institutions SME developers who continuously review development concepts which are suitable, the willingness of financial institutions to provide assistance, and of course the willingness and development of entrepreneurs and self-improvement in the company's revamping.

This study aimed to: (1) Describe the position of potential employers that include competence and commitment of employers in running their business as a small business. (2) Describe the business strength / competitive position and profitability of business and employers with respect to the situation and the internal and external environmental conditions, both on the positive side and negative side.

\section{RESEARCH METHODS}

This study uses a survey method to explain the potential development of small industrial enterprises. Geulis Umbrella which is a typical craft in the District of Tasikmalaya (explanatory research). Entire study population was the small industries in the district of Tasikmalaya Geulis Umbrella. In accordance with the formulation of the problem, the host of research, hypothesis formulation and type of data collected, the methods used in this study is a descriptive analysis using SWOT analysis. SWOT analysis is a creative process in planning strategies, policies and programs of work with attention to the situation and the internal and external environmental conditions, 
both on the positive side and negative side. In other words, SWOT analysis is to identification various factors systematically to formulate corporate strategy by maximizing the strengths and opportunities, but at the same time to minimize weaknesses and threats (Freddy Rangkuti, 1997: 19).

One of the things that make an SME business have good results are the business planning. Planning a business is based on the analysis of several factors that will affect the continuity of the business. One approach to analysis it is the SWOT analysis (Strength, Weakness, Oportunity, Threats). SWOT Analysis is a strategic planning method used to evaluate the Strengths, Weaknesses, Opportunities, and Threats involved in a business or enterprise. SWOT analysis is a tool of analysis the determining business objectives by identifying internal and external factors which are good and not good for certain purposes. SWOT analysis can be applied to analyze the business continuity of Small and Medium Enterprises (SMEs). A small business will have a solid foundation to success, if it has a clear thought through some analysis of the factors that affect a business.

SWOT analysis must first begin by defining what the goals of the business are. SWOT analysis can be used as an ingredient to make strategic planning a business venture of SMEs, based on the factors of our strengths, our weaknesses, opportunities and the challenge, especially the competitor force. By considering a few things based on the SWOT analysis can determine and predictable business development. If the goal is not achieved, we have to define a more rational goal. In business continuity, there are two things that can affect the success of the business. First and Second Internal factors External factors. SWOT analysis is used to identify internal and external factors that are important in achieving objectives.

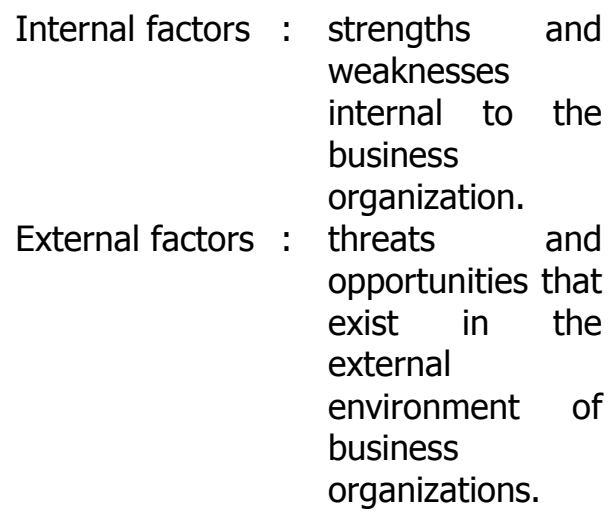

By knowing the weaknesses we have, we can anticipate the failure of a business. Having analyzed the weaknesses of a business owned by us, wherever we may take immediate steps to address these weaknesses. Example if our weakness is the factor of production is slow means the production that should certainly replace the newer production equipment or modify tools to be more efficient and effective. Suppose we have a product that has a quality above the 
average of similar products, it can be used as ingredients in promotional approach. Opportunitie $s$ as well as the strength of the positive things from the outside that needs to be captured and used as a foundation to run the business. One example, suppose there is a chance the market demand for a product is very large. This is an opportunity that needs to be arrested to serve our business fields.

The

number

of opportunities a

business is certain to be followed by the number of competitors who engaged in same business. This raises the threat to our efforts. The threat of this kind of competition should be anticipated with some steps. For example, by improving product quality, product variety or better marketing methods. As far as possible we minimize weaknesses and threats, but to strengthen the power and potential.

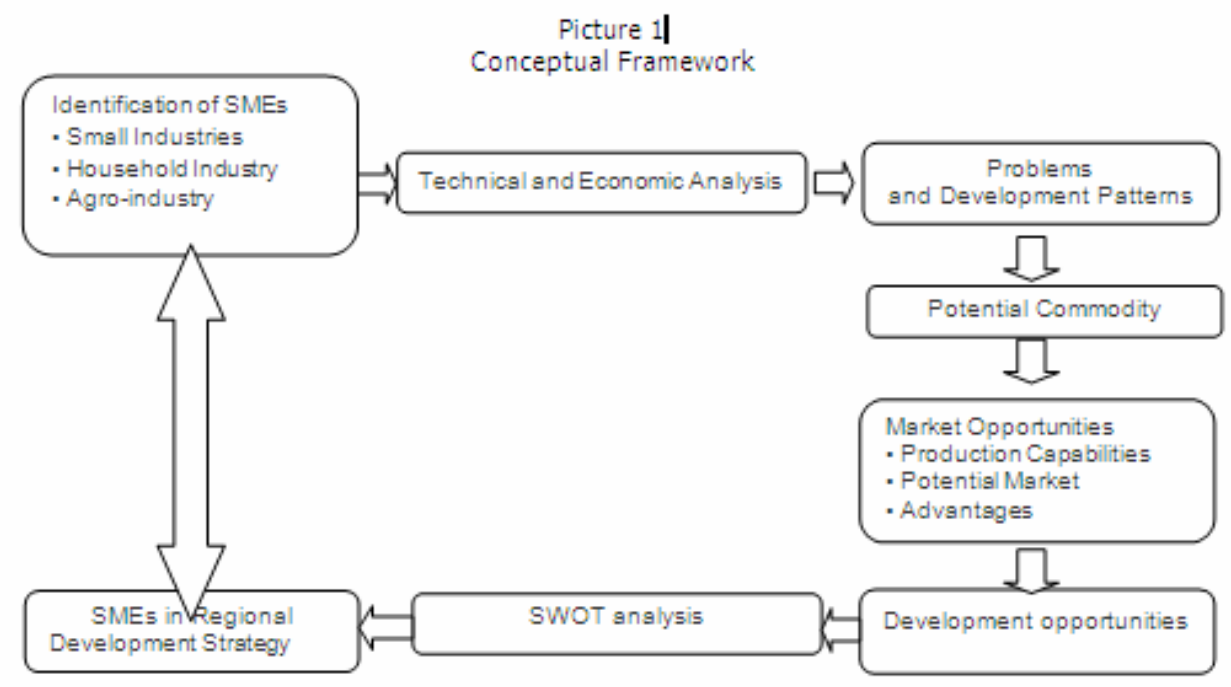

RESULTS AND DISCUSSION

Though based on data that has been presented and the results of observations in the field of industrial enterprises, especially small umbrella geulis shows many and very complex problems. Some of the problems associated with the low human resources quality such as the ability to manage their business activities,

knowledge about the vagaries of the business that is relatively less, minimal managerial skills, financial management and accounting as well as the traditional clan system of wage employees work arrangements are not structured to make their businesses to thrive. 
In addition, other issues also affect business activities such as limited capital, has no business license, low access to markets, access to bank institutions do not exist, ignorance of administrative procedures, continuity and production capacity is limited; coupled with the business climate that has not been conducive to the development of SMEs and new entrepreneurs. Although the various policies and directed credit to small and medium enterprises, but small business handicraft has not been handled by agencies / government. The complexity and the many problems faced by SMEs, coaching them is not an easy and short job. In this case the much needed awareness, partnership, commitment, social sensitivity and great attention, especially from universities to conduct emperment on their efforts.

A variety of coaching programs, and entrepreneurial commi tment made either from government agencies, private sectors and state enterprises. But in fact the program is still far from expectations. Quality and model programs and effective implementation have not been felt, and conducive and productive approaches are project-oriented methods. Consequently, the motivation for developing SMEs are still weak and funders of the original budget runs out, while for SMEs provided soft loans and grant aid was felt that there was no desire to restore them even spend it for the consumer spending that has no connection with the business. Implementation of SME development program both from government and the private sector is more concerned with most aspects of the course highlights the popularity and quality of results rather than fact.

Several facts indicate the number of SMEs and entrepreneurship training institutions do not have valid data on SMEs and their problems. Not to mention every government agency has different issues concerning SMEs so that programs and targets used are also different which results in overlapping assistance programs and coaching as well as just revolve around the specific business and individuals. Though small and medium entrepreneurs who else is still much need for help and coaching programs, including the handicraft industry which is the object of research until now there is no one office building let alone give them assistance.

Judging from the potential entrepreneurs and business handicraft industry shows that the potential employers in the category of being as well as potential business is classified as a category because it is on approaches and strategies based on the situation of enterprises and entrepreneurs held by industry payung geulis. While in its development should be done according to the required employers in terms of capital and managerial skills with attention to the following matters: Development programs carried out in order of priority and 
sustainable programs short, medium and long term. Program development by looking at the crucial and urgent issue owned by an industry umbrella gules.

\section{CONCLUSION AND RECOMMENDATIONS}

Based on the above discussion several conclusions can be drawn as follows: Industry umbrella geulis shows a lot of the problems it faces and very complex. Some of the problems associated with the low quality of human resources such as the ability to manage their business activities, knowledge and insight about the vagaries of the business that is relatively less, minimal managerial skills, financial management and accounting as well as the traditional system of work organization and remuneration of staff unstructured make their businesses hard to develop. Other problems also affect the normal course of business such as limited capital, has no business license, low access to markets, access to financial institutions / banks do not exist, ignorance of administrative procedures, continuity and production capacity is limited; coupled with a business climate that has not been conducive for the development of SMEs and new entrepreneurs.

Although a lot of policies and directed credit scheme to small and medium-sized industry a made but that has never been handled by the agency / government and private agencies. The complexity and the many problems faced by small businesses resulting in industry built it are not an easy job and brief. It takes awareness, partnership, commitment, social sensitivity and great attention, especially from universities to conduct empowerment in their business. In carrying out the business furniture industry need commitment and competence as well. Formal education is classified as conceptual skills are so lacking in support; in terms of strategy analysis is less so it does not dare to take risks. Because thus approaches and strategies based on the situation of enterprises and entrepreneurs that are owned by the industry umbrella geulis. While the development is appropriate in terms of entrepreneurs needed capital and managerial expertise with the notice: (a) Program development is based on the order of priority and sustainable programs short, medium and long term. (B) Program development by looking at the crucial and urgent issue owned by an industry umbrella geulis.

In developing the small and medium enterprises and bamboo handycraft industry in particular can be delivered the following recommendations: Need for support from the government in the form of credit policy by setting interest rates low and the rate of return relative. Instance expected to plunge directly related to the field to do the counseling and guidance against the industry umbrella geulis. Pursuing a strategy of partnership with private parties who are considered successful so necessary coaching and training on management strategies to improve 
conceptually. The role of college or institution for the development of applied technology transfer to SMEs is further enhanced; otherwise industrial entrepreneurs should be more proactive to find the sources of information about aid marketing as well as capital and guidance of institutions that offer these services.

\section{REFERENCES}

Anastasi, Anne \& Susana Urbina. 1997. Phychological Testing. Seventh Edition. Published by Prentice-Hall Inc.

Fandy Tjiptono. 1996. Manajemen Jasa. Penerbit Andi Yogyakarta.

Gronroos, C.1990. Service Management and Marketing: Managing The Moments of Truth in Service Competition. Lexington Books. Lexington. Mass

Handriana.1998. Analisis Kualitas Pelayanan Pendidikan dan Prestasi Belajar Mahasiswa Pada. Perguruan Tinggi Negeri dan Swasta di Surabaya. Thesis Magister Sains. Program Pascasarjana Universitas Padjadjaran Bandung.

Kotler, Philip. 1997. Manajemen Pemasaran: Analisis Perencanaan Implementasi, dan Kontrol. Edisi Bahasa Indonesia. Jilid I. Alih Bahasa. Hendra Teguh dan Ronny A. Penerbit PT Prenhallindo. Jakarta.

Kwik Klan Gie. 1996. Praktek Bisnis dan Orientasi Ekonomi
Indonesia. Penyunting $\mathrm{Y}$. Priyo Utomo \& Sapto Widyatmiko. PT. Gramedia Pustaka Utama Jakarta.

Lovelock, Christopher H. 1991.. Services Marketing. 2th Edition. Prentice Hall International Edition. USA.

Lovelock, Christopher. 1998. Managing Service: Marketing, Operations, and Human Resources. London: PrenticeHall International Inc. Lovelock,Christopher.

Principles of Service Marketing and Management. 1996. London: Prentice-Hall International Inc.

Masri Singarimbun dan Sofian Effendi. 1995. Metode Penelitian Survai. LP3ES. Lembaga Penelitian. Pendidikan dan Penerangan Ekonomi dan sosial.

Moh. Nazir. 1983. Metode Penelitian. Ghalia Indonesia.

Sucherly. 1998. Manajemen Pemasaran Jasa (Service Marketing Management), Pelatihan "Capability Development Program" Skill Development Project-Jawa Barat. Fakultas Ekonomi Universitas Padjadjaran.

Supranto, J. 2000. Statistik: Teori dan Aplikasi. Edisi keenam. Penerbit Erlangga Jakarta.

Sugiyono. 1998. Metode Penelitian Administrast Penerbit CV Alpabeta Bandung.

Parasuraman, Valarie A. Zeithaml, and Leonard L. Berry. 1985. "A Conceptual Model of 
Service Quality and Its Implications for Future Research". Journal of Marketing. Vo1.49 (Fall). pp.41-50.

Zeithaml Valarie. A., Mary Jo Britner. 1996. Services Marketing. The Mcgraw-Hill Companies. Inc. Singapura.

Zeithaml,V.A., Parasuraman, A., and Berry, L. L.. 1990. Delivering Quality Service. The Free Press. New York.

Zeithaml, V.A., Berry, L.L., and Parasuraman, A.. 1990. "The Nature and Determinants of Customer Expectation of Service". Journal of Academy of Marketing Science. Vol.21. No. 1. pp. 1-12.m http://galeriukm.web.id/artikelusaha/kiat-sukses-bisnisusaha-kecil 19 November 2009

http://www.tubasmedia.com/berita/p ayung-geulis-terancampunah/

http://www.kabarpriangan.com/news/detail/80 3

http://issuu.com/komunika/docs/kom unika052010

http://www.tasikmalayakota.go.id/ne w/index.php?option $=$ com_co ntent\&view $=$ article\&id $=175 \&$ catid $=1 \&$ Itemid $=104$ 